\title{
An Effective COVID-19 Vaccine Needs to Engage T Cells
}

\author{
Karsten Sauer* and Tim Harris* \\ Repertoire Immune Medicines, Cambridge, MA, United States
}

Keywords: COVID-19, SARS-CoV-2, T cell, epitope, vaccine, neutralizing antibody, memory, pandemic

\section{INTRODUCTION}

Ending the current COVID-19 pandemic and preventing recurrence requires the development of vaccines that provide long-lasting immunity to the causative virus SARS-CoV-2 and its emerging variants where B cell epitopes can be mutated (1-3). We argue that to achieve this, a vaccine must elicit CD4 and CD8 T cell immunity in addition to the production of neutralizing antibodies (nAB) by B cells. The rationale is based on the following findings for SARS-CoV-2 and the related SARS-CoV virus which caused the 2002/2003 SARS pandemic:

\section{ANTIBODIES ALONE MAY NOT PROTECT SUFFICIENTLY}

\section{OPEN ACCESS}

Edited by:

Lee Mark Wetzler,

Boston University, United States

Reviewed by:

Nina Le Bert,

Duke-NUS Medical School, Singapore

Cosima T. Baldari,

University of Siena, Italy

${ }^{*}$ Correspondence:

Karsten Sauer

ksauer@repertoire.com

Tim Harris

tharris@repertoire.com

Specialty section:

This article was submitted to Vaccines and Molecular Therapeutics,

a section of the journal

Frontiers in Immunology

Received: 09 July 2020

Accepted: 27 August 2020

Published: 28 September 2020

Citation:

Sauer $K$ and Harris T (2020) An Effective COVID-19 Vaccine Needs to

Engage T Cells.

Front. Immunol. 11:581807.

doi: 10.3389/fimmu.2020.581807
Most current vaccine efforts primarily aim to promote $\mathrm{nAB}$ production. However, significant evidence indicates that a robust antibody $(\mathrm{AB})$ response alone is insufficient to avoid severe disease and might even promote it under certain poorly understood circumstances (4). While often critical for virus neutralization and disease control, B cell responses to the SARS-CoV-2 related virus SARS-CoV have been of limited duration and breadth (5-7). Although AB and nAB against SARSCoV-2 are found in most cases of confirmed COVID-19 over time and can correlate inversely with viral load, their correlation with protection is unclear owing to a paucity of data and the use of heterogeneous serological assays with limited sensitivity and specificity (8). Signals in pre-COVID samples also indicate confounding cross-reactivities. In addition, $\mathrm{AB}$ need not protect, might worsen pathology, and high titers associated with more severe COVID-19 and worse outcomes in several studies-reminiscent of findings in SARS $(4,9,10)$. Some unprotected ICU patients had SARS-CoV-2 specific AB, challenging their ability to protect (11). These findings point to a complex role of $\mathrm{AB}$ in COVID-19 that may not always be beneficial. It is also possible that mutational alteration of $B$ cell epitopes could render emerging SARS-CoV-2 variants less sensitive to $B$ cell engaging vaccines targeting earlier variants (2). Moreover, nAB titers declined to near baseline within 2-3 months during convalescence in many PCR-confirmed subjects particularly with mild disease or asymptomatic infection (12-14). Altogether, variable and often low $\mathrm{nAB}$ titers in convalescent patients, and in particular the very low titers or entire absence of $\mathrm{nAB}$ or $\mathrm{AB}$ against SARS-CoV-2 in up to $33 \%$ of recovered patients point to a critical role for other immune mechanisms in recovery from the disease (15-18).

\section{THE CASE FOR T CELLS}

Multiple lines of evidence support important roles for $\mathrm{T}$ cells in productive immune responses to COVID-19. In most SARS patients, $\mathrm{B}$ cell and $\mathrm{nAB}$ responses were relatively short lived (1-2 years) and prone to antigen escape, raising the possibility of re-infection. In contrast, $\mathrm{T}$ cell memory in survivors was long-lived ( $>6-17$ years) $(4-7,19)$. It is well-known that $\mathrm{T}$ cells can engage antigen epitopes that are not targeted by B cells, including those derived from intracellular proteins, to 
provide broader protection which the virus can less easily circumvent through mutation (6). T cells are especially necessary to clear severe virus infections. Altogether, in addition to $\mathrm{nAB}$, eliciting broad and long-lasting antiviral immunity requires the co-enrollment of CD4 and CD8 T cells and the generation of effective T cell memory $(5,6,20-22)$.

The importance of $\mathrm{T}$ cells is further illustrated by the $\mathrm{T}$ cell lymphopenia and exhaustion or dysfunction in both SARS and COVID-19 which increase with disease severity $(5,16,22-$ 28). T cells clonally expand in COVID-19, and convalescence is associated with $\mathrm{T}$ cell recovery and memory formation. Convalescent patients contain SARS-CoV-2 reactive CD4 T cells (up to $100 \%$ of patients) and CD8 T cells ( $70 \%$ of patients), including $\mathrm{CD} 4 \mathrm{~T}_{\mathrm{FH}}$ cells capable of providing help to $\mathrm{B}$ cells (29-32). Consistent with a role for $\mathrm{T}$ cells in helping B cells in COVID-19, virus-specific $\mathrm{T}$ and $\mathrm{T}_{\mathrm{FH}}$ cell numbers correlated with $\mathrm{nAB}$ and $\mathrm{AB}$ titers and deceased COVID-19 patients lacked $\mathrm{T}_{\mathrm{FH}}$ cells and germinal centers in their draining hilar lymph nodes correlated with reduced $\mathrm{AB}$ levels (32-37). T cell reactivities in recovered patients covered multiple SARS-CoV-2 proteins and particularly targeted immunodominant epitopes in the spike (S), membrane $(\mathrm{M})$, and nucleoproteins $(\mathrm{N})$, indicating a benefit for including these proteins in vaccine designs rather than only $\mathrm{S}$ as done in several current vaccines $(32,38)$. It has been shown that S-protein specific CD4 T cells correlate with virus-specific $A B$ titers, but differing approaches and populations have yielded somewhat different antigen hierarchies and more detailed studies are needed to identify the most beneficial epitopes (39). Detection of SARS-CoV-2 cross-reactive CD8 and particularly CD $4 \mathrm{~T}$ cells, probably elicited by endemic common cold causing coronaviruses, in $40-81 \%$ of unexposed individuals may contribute to the relative protection of most people against COVID-19 (16, 19, 29, 30, 37, 40). Further supporting T cell importance, in silico predictions and epidemiologic studies suggest that COVID-19 vulnerability may depend on the HLA haplotype of a person and its capacity to present SARS-CoV2 epitopes to $\mathrm{T}$ cells. In Italy, prevalence of the potentially permissive alleles HLA-B* 44 and $\mathrm{C}^{*} 01$ correlates with COVID19 spread $(41,42)$.

In SARS, both cytotoxic CD8 T cells and CD4 helper T cells were required for virus clearance (20). In COVID-19, several clinical studies have identified reduced CD8 T cells as an early prognostic indicator of severe or lethal disease and treatment efficacy. CD4 help is needed for effective anti-viral responses by both CD8 $\mathrm{T}$ cells and $\mathrm{B}$ cells, including $\mathrm{nAB}$ production $(5,29$, $30,43)$. In particular, airway memory CD4 $\mathrm{T}$ cells are critical for SARS-CoV clearance (6). Although SARS-CoV-2 reactive CD4 and CD8 T cells can be found in severe COVID-19 and can correlate with $\mathrm{AB}$ appearance and lower viral loads, $\mathrm{CD} 4 \mathrm{~T}$ cells in severe disease are often dysfunctional or deregulated compared to mild COVID-19 (10, 23, 28, 30, 32, 37, 44, 45). Conversely, recovering patients had increased virus specific and general CD4 $\mathrm{T}_{\mathrm{FH}}$ cells, and their SARS-CoV-2 reactive $\mathrm{T}$ cells expressed reduced inhibitory markers and elevated effector molecules (25, $34,44,46,47)$.

Supporting the importance of $\mathrm{T}$ cells in controlling COVID19, several studies reported durable $\mathrm{T}$ cell responses in convalescent patients even lacking virus-specific $\mathrm{AB}$. One study found SARS-CoV-2 specific polyfunctional T cells with a stemcell like memory phenotype in convalescent patients that could even be found in $\mathrm{AB}$-seronegative family members and in individuals with a history of asymptomatic or mild COVID-19 (16). Another study found SARS-CoV-2 specific T cells but not $\mathrm{AB}$ in individuals that had been symptomatic within a week post-contact with COVID-19 infected relatives. These T cells persisted for at least 80 days and reached frequencies similar to those found in patients, which were much higher than the amounts in unexposed healthy donors and unlikely to reflect cross-reactivity with other coronaviruses (48). A third study found SARS-CoV-2 specific CD4 and CD8 T cell responses in $56 \%$ of AB-negative subjects (40). Thus, as seen in SARS and MERS, T cell immunity against SARS-CoV-2 can occur in the absence of humoral immunity, might even be more prevalent in certain populations, associates with recovery, can persist longer and might serve as a more sensitive biomarker for exposure $(19,48)$. The relative importance of humoral vs. T cell immunity for protection however, remains to be determined.

\section{T CELL FUNCTION NEEDS TO BE TUNED APPROPRIATELY}

Although $\mathrm{T}$ cells are required for effective virus control, excessive immune responses and a resulting cytokine storm can worsen disease and increase mortality in SARS and COVID-19. This might involve defects in immunosuppressive $\mathrm{T}_{\text {reg }}$ or $\gamma \delta \mathrm{T}$ cells, or the presence of "pathologic" CD4 T cells producing GM-CSF and IL-6 $(5,23,49,50)$. In SARS, severe disease was associated with increased virus-specific polyfunctional CD8 and CD4 T cells and $\mathrm{T}_{\mathrm{H}} 2$ cytokines (20). Encouragingly, strong $\mathrm{T}_{\mathrm{H}} 2$ skewing has not been seen in COVID-19 to date and two leading SARS-CoV2 vaccine candidates elicited $T_{H} 1$ skewed responses in humans $(4,30,31,51,52)$. Anecdotally, COVID-19 patients enter the hospital lymphopenic but begin to have increased respiratory difficulties as their lymphocyte counts start to recover. Consistent with this, SARS-CoV-2 reactive CD4 and CD8 T cells capable of producing effector and $\mathrm{T}_{\mathrm{H}} 1$ cytokines were found in patients with severe COVID (37). Another study found that SARS-CoV2 specific T cells in acute moderate or severe COVID-19 were more activated and proliferating than those in convalescent patients, whose $\mathrm{T}$ cells had more memory-like phenotypes (16). A third study suggests increased proportions of SARSCoV-2 reactive cytotoxic $\mathrm{T}_{\mathrm{FH}}$ cells with dysfunctional/exhausted gene signatures and of clonally expanded cytotoxic CD4 $\mathrm{T}_{\mathrm{H}}$ cells producing myeloid cell attracting chemokines; but underrepresented SARS-CoV-2 reactive suppressive $\mathrm{T}_{\text {reg }}$ cells and polyfunctional $\mathrm{T}_{\mathrm{H}} 1$ and $\mathrm{T}_{\mathrm{H}} 17$ cells in severe vs. mild COVID19 (44). Nevertheless, a clear cause-effect relationship between $\mathrm{T}$ cell phenotype and disease severity remains to be firmly established (39). Promoting T cell function promises improved virus clearance but may be detrimental in some patients, and a better understanding of the respective relevance of various $\mathrm{T}$ cell subsets and phenotypes for mild vs. severe disease is required (37). 
In any case, a vaccine needs to promote desired effector, helper and memory $\mathrm{T}$ cell phenotypes and to tune $\mathrm{T}$ cell reactivity into a productive but safe "window," while avoiding $\mathrm{T}_{\mathrm{H}} 2$ phenotypes, $\mathrm{T}_{\text {reg }}$ cell deregulation, and excessive $\mathrm{T}$ cell activation and exhaustion (39). To enable this, there is an urgent need to chart the time course, reactivities, and phenotypes of $\mathrm{T}$ cells against SARS-CoV-2 epitopes in healthy subjects and patients with different disease courses. Supporting a role for $\mathrm{T}$ cell reactivity and specificity in driving phenotype, a recent study found that in convalescent patients, SARS-CoV-2 S-protein specific CD4T cells were skewed toward a circulating $\mathrm{T}_{\mathrm{FH}}$ phenotype, whereas $\mathrm{M}$ - and $\mathrm{N}$-protein specific CD4 T cells were skewed toward a $\mathrm{T}_{\mathrm{H}} 1$ or a $\mathrm{T}_{\mathrm{H}} 1 / \mathrm{T}_{\mathrm{H}} 17$ profile (16). Another study found more multifunctional CD8 $\mathrm{T}$ cells targeting $\mathrm{M}$ and $\mathrm{N}$ than $S$ in mild COVID-19 (32). Consistent with pathophysiological relevance of these observations, details of the SARS-CoV-2 T cell antigen hierarchy may differ with disease severity (39).

\section{A NEED FOR DECODING REACTIVITIES, PHENOTYPES, AND RECOGNIZED EPITOPES OF SARS-CoV-2 REACTIVE T CELLS}

A recent review highlighted the importance of determining how SARS-CoV-2 impacts the $\mathrm{T}$ cell repertoire, and how the COVID-19 associated lymphopenia or disease predisposing comorbidities impact it (53). As discussed there, the importance of the $\mathrm{T}$ cell repertoire has long been recognized in other virus infections. In Influenza patients, the presence of specific $\mathrm{T}$ cell clones correlated with antiviral immunity, and an aging (thus more restricted) repertoire associated with increased infection. Influenza-epitope specific public T cell clonotypes that are shared between individuals have been identified (54). Such repertoire convergence is probably broadly relevant for virus infections, because T cell receptor (TCR) $\beta$ profiling has shown convergent repertoire evolution in individuals infected with cytomegalovirus (CMV) or vaccinated against Yellow Fever $(53,55,56)$. Public TCRs have also been used to identify smallpox vaccinated mice with $>99 \%$ accuracy $(53,57)$. This suggests that generalizable, convergent features of the $\mathrm{T}$ cell repertoire correlate with protection. Clearly the most convergent feature is $\mathrm{T}$ cell reactivity against certain antigenic epitopes. Hence it is possible that decoded antigen epitopes for convergent $\mathrm{T}$ cell clonotypes can be used for development of improved, $T$ cell engaging vaccines against SARS-CoV-2. If the different phenotype skewing of $\mathrm{T}$ cells against different SARS-CoV-2 proteins confirms in other studies, an optimized choice of antigens or even epitopes might be able to instruct desired $\mathrm{T}$ cell phenotypes over undesired ones. Decoded T cell reactivities could also be used as sensitive correlates of protection, or to distinguish previously exposed individuals from unexposed ones and act as a biomarker of herd immunity even in $\mathrm{AB}$ seronegative individuals (16). Decoding matched $\mathrm{T}$ cell clonotypes, phenotypes and antigenic epitopes in COVID-19 patients will also answer the important questions as to which characteristics of the $\mathrm{T}$ cell repertoire explain the higher risk of the elderly, and how HLA genetic diversity contributes to the SARS-CoV-2 specific T cell repertoire and immune response (53). Such studies are now possible thanks to recent advances in single cell sequencing technologies combined with largescale HLA tetramer or HLA reporter gene-based epitope library screening technologies $(38,58-66)$.

Indeed, several recent studies reported initial results from profiling $\mathrm{B}$ cell receptor (BCR) and TCR repertoires in COVID-19 patients $(27,45,67,68)$. Consistent with the data from other virus infections, they report convergent $B$ cell clonotypic responses closely associated with SARS-CoV-2 AB. Somatic hypermutation analyses suggest a primary immune response involving naive $\mathrm{B}$ cells. Higher somatic hypermutation is associated with more severe disease, which also showed skewed BCR gene usage (27). Moreover, SARS-CoV-2 T cell responses were highly clonal in active disease and driven by TCR clusters shared between patients particularly after recovery, which showed characteristic clonotype trajectories over the disease course. Reduced $\mathrm{T}$ cell clonal expansion and skewed TCR gene usage in severe disease could indicate that different immunodominant antigen epitopes drive distinct $\mathrm{T}$ cell clonotypes and fates in mild vs. severe COVID-19 (27). A vaccine therefore may need to exclude $\mathrm{B}$ cell and $\mathrm{T}$ cell epitopes driving severe disease.

Additional recent studies have decoded blood $\mathrm{T}$ cell clonotypes and recognized antigen epitopes restricted by HLA class I or II in mostly convalescent COVID-19 patients and controls $(19,32,38,40,67,69,70)$. Taken together, the studies show that anti-SARS-CoV-2 $\mathrm{T}$ cell responses target immunodominant epitopes broadly spread across the viral proteome mostly beyond the $\mathrm{S}$ protein, involve convergent and shared $\mathrm{T}$ cell clonotypes among patients and persist for several months post-recovery. Epitope localization outside regions with high mutational variation could suggest that $\mathrm{T}$ cell vaccine responses may not be prone to virus escape (69). An increased diversity but not intensity of SARS-CoV$2 \mathrm{~T}$ cell responses is associated with recovery from mild vs. severe disease (40). This may suggest that development of protective immunity requires recognition of multiple virus epitopes, arguing for including multiple SARS-CoV-2 antigens in vaccine design. However, in another study, responses appeared larger with a broader epitope coverage in severe patients $(32,39)$. Interestingly, several studies suggest shifted SARS-CoV-2 epitope hierarchies between COVID-19 patients and unexposed individuals harboring SARS-CoV-2 reactive $\mathrm{T}$ cells $(19,30,32)$. In one study, unexposed individuals had cross-reactive $\mathrm{T}$ cells to $31 \%$ of identified HLA-I and $70 \%$ of HLA-II restricted epitopes (40). This may reflect previous infections with various betacoronaviruses or other crossreactivities whose physiological relevance remains to be elucidated.

These results revise the previously reported $\mathrm{T}$ cell antigen hierarchies dominated by $\mathrm{S}, \mathrm{M}$, and $\mathrm{N}$ to include ORF1 and other proteins. They emphasize the benefit of targeting $\mathrm{T}$ cells for development of broadly protective vaccines and highlight the need to include antigens beyond $S$, although broader studies covering more HLA haplotypes and including CD4 T cells are needed to identify the most promiscuous epitopes across large 
human populations, including $\mathrm{N}_{81-120}(19,32,39)$. The precise impact of virus reactive $\mathrm{T}$ cell clonotypes and their epitope specificity and phenotype on disease course, and their prognostic relevance remain to be elucidated. Pointing to the latter, profiling a subject's TCR repertoire worked as a diagnostic for past or current COVID-19 even in absence of virus-specific AB (67).

\section{CURRENT VACCINE CANDIDATES ENGAGE T CELLS TO A LIMITED EXTENT}

Several recent publications provide glimpses into how the most advanced current candidate SARS-CoV-2 vaccines engage $\mathrm{T}$ cells. All target the S-protein or its receptor-binding domain (RBD). In clinical trials, most candidates elicited robust $\mathrm{nAB}$ responses similar to or exceeding those in convalescent serum within the limited follow-up periods reported (51, 52, 71, 72). A human adenovirus based vaccine targeting $S$ had limited immunogenicity due to high pre-existing anti-adenovirus $\mathrm{nAB}$ in many subjects $(73,74)$. Among all candidates, $\mathrm{T}$ cell responses were variable with frequencies of $100 / 10^{6}-856 / 10^{6}$ IFN $\gamma$-producing, virus-specific peripheral blood derived CD4 and CD8 T cells in ELISPOT assays. A chimpanzee adenovirus based vaccine targeting the $\mathrm{S}$ protein elicited $\mathrm{S}$-specific $\mathrm{T}$ cell responses lasting at least 56 days in many subjects (71). In contrast, the human adenovirus based vaccine elicited more limited virus-reactive $\mathrm{T}$ cells in $\leq 90 \%$ of subjects after 28 days $(73,74)$. One mRNA vaccine targeting the RBD caused $\mathrm{RBD}$-specific CD8 $\mathrm{T}$ cell responses similar to, and $\mathrm{T}_{\mathrm{H}} 1$ skewed $\mathrm{CD} 4 \mathrm{~T}$ cell responses exceeding memory responses to $\mathrm{CMV}$, EBV, influenza \& tetanus toxoid in $>80 \%$ of participants within 29 days, which correlated with nAB titers and varied among individuals (52). Similarly, another mRNA vaccine targeting $\mathrm{S}$ elicited $\mathrm{T}_{\mathrm{H}} 1$-skewed $\mathrm{S}$-protein specific CD4 $\mathrm{T}$

\section{REFERENCES}

1. Hadfield J, Megill C, Bell SM, Huddleston J, Potter B, Callender C, et al. Nextstrain: real-time tracking of pathogen evolution. Bioinformatics. (2018) 34:4121-3. doi: 10.1093/bioinformatics/bty407

2. Kim SJ, Nguyen VG, Park YH, Park BK, Chung HC. A novel synonymous mutation of SARS-CoV-2: is this possible to affect their antigenicity and immunogenicity? Vaccines. (2020) 8:220. doi: 10.3390/vaccines 8020220

3. Lorenzo-Redondo R, Nam HH, Roberts SC, Simons LM, Jennings LJ, Qi C, et al. A unique clade of SARS-CoV-2 viruses is associated with lower viral loads in patient upper airways. medRxiv. (2020). doi: 10.1101/2020.05.19.20107144

4. Vabret N, Britton GJ, Gruber C, Hegde S, Kim J, Kuksin M, et al. Immunology of COVID-19: current state of the science. Immunity. (2020) 52:910-41. doi: 10.1016/j.immuni.2020.05.002

5. Channappanavar R, Zhao J, Perlman S. T cell-mediated immune response to respiratory coronaviruses. Immunol Res. (2014) 59:118-28. doi: 10.1007/s12026-014-8534-Z

6. Zhao J, Zhao J, Mangalam AK, Channappanavar R, Fett C, Meyerholz $\mathrm{DK}$, et al. Airway memory CD4(+) T cells mediate protective immunity against emerging respiratory coronaviruses. Immunity. (2016) 44:1379-91. doi: 10.1016/j.immuni.2016.05.006

7. Lin Q, Zhu L, Ni Z, Meng H, You L. Duration of serum neutralizing antibodies for SARS-CoV-2: lessons from SARS-CoV infection. J Microbiol Immunol Infect. (2020). doi: 10.1016/j.jmii.2020.03.015. [Epub ahead of print]. cell but low CD8 $\mathrm{T}$ cell responses within 43 days in most subjects (51).

For all candidates, it remains unclear whether the $\mathrm{T}$ cell responses are high enough for robust and lasting protection. Because they only target $S$, all fail to leverage the majority of SARS-CoV-2 T cell epitopes that are clearly targeted in naturally infected individuals. Thus, a strong need remains for vaccines leveraging all $\mathrm{T}$ cell epitopes, and for large phase 3 trials to demonstrate durable efficacy in diverse human populations.

\section{CONCLUSION}

Altogether, the data reviewed here point toward an important need to design COVID-19 vaccines which co-engage $\mathrm{T}$ cells in addition to $\mathrm{B}$ cells. They also highlight the benefit of decoding matched $\mathrm{T}$ cell reactivities, phenotypes and antigenic epitopes in the context of the major human HLA haplotypes for development of both vaccines and TCR based diagnostics for this devastating disease.

\section{AUTHOR CONTRIBUTIONS}

All authors conceived and wrote the manuscript together.

\section{FUNDING}

This work was funded entirely by Repertoire Immune Medicines, Inc.

\section{ACKNOWLEDGMENTS}

We thank Andrea DiFabio and John Cox for critical reading of the manuscript, and our colleagues for stimulating discussions.

8. Whitman JD, Hiatt J, Mowery CT, Shy BR, Yu R, Yamamoto TN, et al. Test performance evaluation of SARS-CoV-2 serological assays. medRxiv. (2020) doi: 10.1101/2020.04.25.20074856

9. Cao X. COVID-19: immunopathology and its implications for therapy. Nat Rev Immunol. (2020) 20:269-70. doi: 10.1038/s41577-020-0308-3

10. Oja AE, Saris A, Ghandour CA, Kragten NAM, Hogema BM, Nossent EJ, et al. Divergent SARS-CoV-2-specific T and B cell responses in severe but not mild COVID-19. bioRxiv. (2020). doi: 10.1101/2020.06.18.159202

11. Shen C, Wang Z, Zhao F, Yang Y, Li J, Yuan J, et al. Treatment of 5 Critically Ill Patients With COVID-19 With Convalescent Plasma. JAMA. (2020) 323:1582-9. doi: 10.1001/jama.2020.4783

12. Ibarrondo FJ, Fulcher JA, Goodman-Meza D, Elliott J, Hofmann C, Hausner $\mathrm{MA}$, et al. Rapid decay of anti-SARS-CoV-2 antibodies in persons with mild covid-19. N Engl J Med. (2020) 383:1085-7. doi: 10.1056/NEJMc202 5179

13. Long QX, Tang XJ, Shi QL, Li Q, Deng HJ, Yuan J, et al. Clinical and immunological assessment of asymptomatic SARS-CoV-2 infections. Nat Med. (2020) 26:1200-4. doi: 10.1038/s41591-020-0965-6

14. Seow J, Graham C, Merrick B, Acors S, Steel KJA, Hemmings O, et al. Longitudinal evaluation and decline of antibody responses in SARS-CoV-2 infection. medRxiv. (2020). doi: 10.1101/2020.07.09.20148429

15. Robbiani DF, Gaebler C, Muecksch F, Lorenzi JCC, Wang Z, Cho A, et al. Convergent antibody responses to SARS-CoV-2 in convalescent individuals. Nature. (2020) 584:437-42. doi: 10.1038/s41586-020-2456-9 
16. Sekine T, Perez-Potti A, Rivera-Ballesteros O, Strålin K, Gorin JB, Olsson A, et al. Robust $\mathrm{T}$ cell immunity in convalescent individuals with asymptomatic or mild COVID-19. Cell. (2020). doi: 10.1016/j.cell.2020.08.017. [Epub ahead of print].

17. Wu F, Wang A, Liu M, Wang Q, Chen J, Xia S, et al. Neutralizing antibody responses to SARS-CoV-2 in a COVID-19 recovered patient cohort and their implications. medRxiv. (2020). doi: 10.2139/ssrn.3566211

18. Zhao J, Yuan Q, Wang H, Liu W, Liao X, Su Y, et al. Antibody responses to SARS-CoV-2 in patients of novel coronavirus disease 2019. Clin Infect Dis. (2020). doi: 10.1093/cid/ciaa344. [Epub ahead of print].

19. Le Bert N, Tan AT, Kunasegaran K, Tham CYL, Hafezi M, Chia A, et al. SARS-CoV-2-specific $T$ cell immunity in cases of COVID19 and SARS, and uninfected controls. Nature. (2020) 584:457-62. doi: 10.1038/s41586-020-2550-Z

20. Li CK, Wu H, Yan H, Ma S, Wang L, Zhang M, et al. T cell responses to whole SARS coronavirus in humans. J Immunol. (2008) 181:5490-500. doi: 10.4049/jimmunol.181.8.5490

21. Channappanavar R, Fett C, Zhao J, Meyerholz DK, Perlman S. Virus-specific memory CD8 T cells provide substantial protection from lethal severe acute respiratory syndrome coronavirus infection. J Virol. (2014) 88:11034-44. doi: 10.1128/JVI.01505-14

22. Vardhana SA, Wolchok JD. The many faces of the anti-COVID immune response. J Exp Med. (2020) 217:e20200678. doi: 10.1084/jem.20200678

23. Diao B, Wang C, Tan Y, Chen X, Liu Y, Ning L, et al. Reduction and functional exhaustion of T cells in patients with coronavirus disease 2019 (COVID-19). Front Immunol. (2020) 11:827. doi: 10.3389/fimmu.2020.00827

24. Tan L, Wang Q, Zhang D, Ding J, Huang Q, Tang YQ, et al. Lymphopenia predicts disease severity of COVID-19: a descriptive and predictive study. Signal Transduct Target Ther. (2020) 5:33. doi: 10.1038/s41392-020-0159-1

25. Thevarajan I, Nguyen THO, Koutsakos M, Druce J, Caly L, Van De Sandt $\mathrm{CE}$, et al. Breadth of concomitant immune responses prior to patient recovery: a case report of non-severe COVID-19. Nat Med. (2020) 26:453-5. doi: 10.1038/s41591-020-0819-2

26. Wang F, Nie J, Wang H, Zhao Q, Xiong Y, Deng L, et al. Characteristics of peripheral lymphocyte subset alteration in COVID-19 pneumonia. J Infect Dis. (2020) 221:1762-9. doi: 10.1093/infdis/jiaa150

27. Zhang JY, Wang XM, Xing X, Xu Z, Zhang C, Song JW, et al. Singlecell landscape of immunological responses in patients with COVID-19. Nat Immunol. (2020) 21:1107-18. doi: 10.1038/s41590-020-0762-x

28. Zheng HY, Zhang M, Yang CX, Zhang N, Wang XC, Yang XP, et al. Elevated exhaustion levels and reduced functional diversity of $\mathrm{T}$ cells in peripheral blood may predict severe progression in COVID-19 patients. Cell Mol Immunol. (2020) 17:541-3. doi: 10.1038/s41423-020-0401-3

29. Braun J, Loyal L, Frentsch M, Wendisch D, Georg P, Kurth F, et al. SARS-CoV2-reactive $\mathrm{T}$ cells in healthy donors and patients with COVID-19. Nature. (2020). doi: 10.1038/s41586-020-2598-9

30. Grifoni A, Weiskopf D, Ramirez SI, Mateus J, Dan JM, Moderbacher CR, et al. Targets of $\mathrm{T}$ cell responses to SARS-CoV-2 coronavirus in humans with COVID-19 disease and unexposed individuals. Cell. (2020) 181:1489-501.e15. doi: 10.1016/j.cell.2020.05.015

31. Neidleman J, Luo X, Frouard J, Xie G, Gurjot G, Stein ES, et al. SARSCoV-2-specific $\mathrm{T}$ cells exhibit unique features characterized by robust helper function, lack of terminal differentiation, and high proliferative potential. bioRxiv. (2020). doi: 10.1101/2020.06.08.138826

32. Peng Y, Mentzer AJ, Liu G, Yao X, Yin Z, Dong D, et al. Broad and strong memory CD4 (+) and CD8 (+) $\mathrm{T}$ cells induced by SARS-CoV-2 in UK convalescent COVID-19 patients. bioRxiv. (2020). doi: 10.1101/2020.06.05.134551

33. Duan YQ, Xia MH, Ren L, Zhang YF, Ao QL, Xu SP, et al. Deficiency of Tfh cells and germinal center in deceased COVID-19 patients. Curr Med Sci. (2020) 40:618-24. doi: 10.1007/s11596-020-2225-x

34. Juno JA, Tan HX, Lee WS, Reynaldi A, Kelly HG, Wragg K, et al. Humoral and circulating follicular helper $\mathrm{T}$ cell responses in recovered patients with COVID-19. Nat Med. (2020) 26, 1428-34. doi: 10.1038/s41591-020-0995-0

35. Kaneko N, Kuo HH, Boucau J, Farmer JR, Allard-Chamard H, Mahajan VS, et al. The loss of Bcl-6 expressing $\mathrm{T}$ follicular helper cells and the absence of germinal centers in COVID-19. SSRN. (2020) 3652322. doi: $10.2139 /$ ssrn. 3652322
36. Ni L, Ye F, Cheng ML, Feng Y, Deng YQ, Zhao H, et al. Detection of SARS-CoV-2-specific humoral and cellular immunity in COVID19 convalescent individuals. Immunity. (2020) 52:971-7.e973. doi: 10.1016/j.immuni.2020.04.023

37. Weiskopf D, Schmitz KS, Raadsen MP, Grifoni A, Okba NMA, Endeman $\mathrm{H}$, et al. Phenotype and kinetics of SARS-CoV-2-specific T cells in COVID19 patients with acute respiratory distress syndrome. Sci Immunol. (2020) 5:eabd2071. doi: 10.1126/sciimmunol.abd2071

38. Chour W, Xu AM, Ng AHC, Choi J, Xie J, Yuan D, et al. Shared antigen-specific CD8 $+\mathrm{T}$ cell responses against the SARS-COV-2 spike protein in HLA A*02:01 COVID-19 participants. medRxiv. (2020). doi: 10.1101/2020.05.04.20085779

39. Altmann DM, Boyton RJ. SARS-CoV-2 T cell immunity: specificity, function, durability, and role in protection. Sci Immunol. (2020) 5:eabd6160. doi: 10.1126/sciimmunol.abd6160

40. Nelde A, Bilich T, Heitmann JS, Maringer Y, Salih HR, Roerden M, et al. SARS-CoV-2 T-cell epitopes define heterologous and COVID19-induced T-cell recognition. Res Square. (2020). doi: 10.21203/rs.3.rs$35331 / \mathrm{v} 1$

41. Correale P, Mutti L, Pentimalli F, Baglio G, Saladino RE, Sileri P, et al. HLA$\mathrm{B}^{*} 44$ and $\mathrm{C}^{*} 01$ prevalence correlates with Covid 19 spreading across Italy. Int J Mol Sci. (2020) 21:5205. doi: 10.3390/ijms21155205

42. Nguyen A, David JK, Maden SK, Wood MA, Weeder BR, Nellore A, et al. Human leukocyte antigen susceptibility map for severe acute respiratory syndrome coronavirus 2. J Virol. (2020) 94:e00510-20. doi: 10.1128/JVI.00510-20

43. Elsaesser H, Sauer K, Brooks DG. IL-21 is required to control chronic viral infection. Science. (2009) 324:1569-72. doi: 10.1126/science.11 74182

44. Meckiff BJ, Ramirez-Suastegui C, Fajardo V, Chee SJ, Kusnadi A, Simon H, et al. Single-cell transcriptomic analysis of SARS-CoV-2 reactive CD4 (+) T cells. SSRN. (2020) 3641939. doi: 10.2139/ssrn.3641939

45. Schultheiss C, Paschold L, Simnica D, Mohme M, Willscher E, Von Wenserski $\mathrm{L}$, et al. Next-generation sequencing of $\mathrm{T}$ and $\mathrm{B}$ cell receptor repertoires from COVID-19 patients showed signatures associated with severity of disease. Immunity. (2020) 53:442-55.e4. doi: 10.1016/j.immuni.2020. 06.024

46. Yang X, Dai T, Zhou X, Qian H, Guo R, Lei L, et al. Analysis of adaptive immune cell populations and phenotypes in the patients infected by SARSCoV-2. (2020) medRxiv. doi: 10.1101/2020.03.23.20040675

47. Zheng M, Gao Y, Wang G, Song G, Liu S, Sun D, et al. Functional exhaustion of antiviral lymphocytes in COVID-19 patients. Cell Mol Immunol. (2020) 17:533-5. doi: 10.1038/s41423-020-0402-2

48. Gallais F, Velay A, Wendling MJ, Nazon C, Partisani M, Sibilia J, et al. Intrafamilial exposure to SARS-CoV-2 induces cellular immune response without seroconversion. medRxiv. (2020). doi: 10.1101/2020.06.21.201 32449

49. Mehta P, Mcauley DF, Brown M, Sanchez E, Tattersall RS, Manson JJ, et al. COVID-19: consider cytokine storm syndromes and immunosuppression. Lancet. (2020) 395:1033-4. doi: 10.1016/S0140-6736(20)30628-0

50. Wei H, Xu X, Tian Z, Sun R, Qi Y, Zhao C, et al. Pathogenic Tcells and inflammatory monocytes incite inflammatory storms in severe COVID-19 patients. Nat Sci Rev. (2020) 7:998-1002. doi: 10.1093/nsr/nw aa041

51. Jackson LA, Anderson EJ, Rouphael NG, Roberts PC, Makhene M, Coler RN, et al. An mRNA vaccine against SARS-CoV-2 - preliminary report. $N$ Engl J Med. (2020). doi: 10.1056/NEJMoa2022483

52. Sahin U, Muik A, Derhovanessian E, Vogler I, Kranz LM, Vormehr M, et al. Concurrent human antibody and TH1 type T-cell responses elicited by a COVID-19 RNA vaccine. medRxiv. (2020). doi: 10.1101/2020.07.17.201 40533

53. Gutierrez L, Beckford J, Alachkar H. Deciphering the TCR repertoire to solve the COVID-19 mystery. Trends Pharmacol Sci. (2020) 41:518-30. doi: 10.1016/j.tips.2020.06.001

54. Sant S, Grzelak L, Wang Z, Pizzolla A, Koutsakos M, Crowe J, et al. Singlecell approach to influenza-specific $\mathrm{CD} 8(+) \mathrm{T}$ cell receptor repertoires across different age groups, tissues, and following influenza virus infection. Front Immunol. (2018) 9:1453. doi: 10.3389/fimmu.2018.01453 
55. Emerson RO, Dewitt WS, Vignali M, Gravley J, Hu JK, Osborne EJ, et al. Immunosequencing identifies signatures of cytomegalovirus exposure history and HLA-mediated effects on the T cell repertoire. Nat Genet. (2017) 49:65965. doi: 10.1038/ng.3822

56. Pogorelyy MV, Minervina AA, Touzel MP, Sycheva AL, Komech EA, Kovalenko EI, et al. Precise tracking of vaccine-responding $T$ cell clones reveals convergent and personalized response in identical twins. Proc Natl Acad Sci USA. (2018) 115:12704-9. doi: 10.1073/pnas.1809 642115

57. Wolf K, Hether T, Gilchuk P, Kumar A, Rajeh A, Schiebout C, et al. Identifying and tracking low-frequency virus-specific TCR clonotypes using high-throughput sequencing. Cell Rep. (2018) 25:2369-78.e4. doi: 10.1016/j.celrep.2018.11.009

58. Han A, Glanville J, Hansmann L, Davis MM. Linking T-cell receptor sequence to functional phenotype at the single-cell level. Nat Biotechnol. (2014) 32:68492. doi: 10.1038/nbt.2938

59. Gee MH, Han A, Lofgren SM, Beausang JF, Mendoza JL, Birnbaum ME, et al. Antigen identification for orphan T cell receptors expressed on tumor-infiltrating lymphocytes. Cell. (2018) 172:549-63.e16. doi: 10.1016/j.cell.2017.11.043

60. Graham DB, Luo C, O'connell DJ, Lefkovith A, Brown EM, Yassour $\mathrm{M}$, et al. Antigen discovery and specification of immunodominance hierarchies for MHCII-restricted epitopes. Nat Med. (2018) 24:1762-72. doi: 10.1038/s41591-018-0203-7

61. Hu Z, Anandappa AJ, Sun J, Kim J, Leet DE, Bozym DJ, et al. A cloning and expression system to probe T-cell receptor specificity and assess functional avidity to neoantigens. Blood. (2018) 132:1911-21. doi: 10.1182/blood-2018-04-843763

62. Joglekar AV, Leonard MT, Jeppson JD, Swift M, Li G, Wong S, et al. T cell antigen discovery via signaling and antigen-presenting bifunctional receptors. Nat Methods. (2019) 16:191-8. doi: 10.1038/s41592-0180304-8

63. Kisielow J, Obermair FJ, Kopf M. Deciphering CD4(+) T cell specificity using novel MHC-TCR chimeric receptors. Nat Immunol. (2019) 20:652-62. doi: 10.1038/s41590-019-0335-z

64. Kula T, Dezfulian MH, Wang CI, Abdelfattah NS, Hartman ZC, Wucherpfennig KW, et al. T-Scan: a genome-wide method for the systematic discovery of $\mathrm{T}$ cell epitopes. Cell. (2019) 178:1016-28.e13. doi: 10.1016/j.cell.2019.07.009

65. Gejman RS, Jones HF, Klatt MG, Chang AY, Oh CY, Chandran SS, et al. Identification of the targets of T-cell receptor therapeutic agents and cells by use of a high-throughput genetic platform. Cancer Immunol Res. (2020) 8:672-84. doi: 10.1158/2326-6066.CIR-19-0745

66. Joglekar AV, Li G. T cell antigen discovery. Nat Methods. (2020) doi: 10.1038/s41592-020-0867-z

67. Snyder TM, Gittelman RM, Klinger M, May DH, Osborne EJ, Taniguchi $\mathrm{R}$, et al. Magnitude and dynamics of the T-cell response to SARS-CoV-2 infection at both individual and population levels. medRxiv. (2020). doi: 10.1101/2020.07.31.20165647

68. Unterman A, Sumida TS, Nouri N, Yan X, Zhao AY, Gasque V, et al. Single-cell omics reveals dyssynchrony of the innate and adaptive immune system in progressive COVID-19. medRxiv. (2020). doi: 10.1101/2020.07.16.20153437

69. Ferretti AP, Kula T, Wang Y, Nguyen DMV, Weinheimer A, Dunlap GS, et al. COVID-19 patients form memory CD8 $+\mathrm{T}$ cells that recognize a small set of shared immunodominant epitopes in SARS-CoV-2. medRxiv. (2020). doi: $10.2139 /$ ssrn.3669387

70. Mateus J, Grifoni A, Tarke A, Sidney J, Ramirez SI, Dan $\mathrm{JM}$, et al. Selective and cross-reactive SARS-CoV-2T cell epitopes in unexposed humans. Science. (2020) eabd3871. doi: $10.1126 /$ science.abd 3871

71. Folegatti PM, Ewer KJ, Aley PK, Angus B, Becker S, Belij-Rammerstorfer $\mathrm{S}$, et al. Safety and immunogenicity of the ChAdOx1 nCoV-19 vaccine against SARS-CoV-2: a preliminary report of a phase $1 / 2$, single-blind, randomised controlled trial. Lancet. (2020) 396:467-78. doi: 10.1016/S0140-6736(20)31604-4

72. Mulligan MJ, Lyke KE, Kitchin N, Absalon J, Gurtman A, Lockhart S, et al. Phase $1 / 2$ study of COVID19 RNA vaccine BNT162b1 in adults. Nature. (2020). doi: $10.1038 / \mathrm{s} 41586-020-2639-4$

73. Zhu FC, Guan XH, Li YH, Huang JY, Jiang T, Hou LH, et al. Immunogenicity and safety of a recombinant adenovirus type-5-vectored COVID-19 vaccine in healthy adults aged 18 years or older: a randomised, double-blind, placebo-controlled, phase 2 trial. Lancet. (2020) 396:479-88. doi: 10.1016/S0140-6736(20)31605-6

74. Zhu FC, Li YH, Guan XH, Hou LH, Wang WJ, Li JX, et al. Safety, tolerability, and immunogenicity of a recombinant adenovirus type-5 vectored COVID-19 vaccine: a dose-escalation, open-label, non-randomised, first-in-human trial. Lancet. (2020) 395:1845-54. doi: 10.1016/S0140-6736(20)31208-3

Conflict of Interest: The authors declare that this study received funding from Repertoire Immune Medicines, Inc. The funder had the following involvement in the study: Both authors are full-time employees of Repertoire and have equity interest in it. Repertoire funded all work and provided equipment. Repertoire employees internally reviewed the manuscript, provided comments and cleared the manuscript for publication.

Copyright (c) 2020 Sauer and Harris. This is an open-access article distributed under the terms of the Creative Commons Attribution License (CC BY). The use, distribution or reproduction in other forums is permitted, provided the original author(s) and the copyright owner(s) are credited and that the original publication in this journal is cited, in accordance with accepted academic practice. No use, distribution or reproduction is permitted which does not comply with these terms. 